\title{
"Conducting is Everywhere!" A Case Study of the Development of Preservice Music Teacher Occupational Identity in a Beginning Conducting Course
}

\author{
Erik Johnson \\ Correspondence: Colorado State University, Fort Collins, Colorado
}

Received: May 23, 2014

Accepted: June 6, 2014

Online Published: June 17, 2014

doi:10.11114/jets.v2i3.422

URL: http://dx.doi.org/10.11114/jets.v2i3.422

\begin{abstract}
Research on pre-service music teacher occupational identity often highlights two competing identities: performer and teacher (L'Roy, 1983; Roberts, 1991; Pellegrino, 2009). Of the many factors that contribute to the occupational identity of the pre-service music teacher (Woodford, 2002), conducting has the potential to integrate performer and teacher identities. Previous research indicates that high school and college ensemble conductors have an influence on the occupational identity of the pre-service music teacher (L'Roy, 1983; Bauer \& Berg, 2001; Isbell, 2008), yet little is known about how socialization to the norms of a conducting community influences the development of pre-service music teacher occupational identity. The present investigation used qualitative case study methodology (Stake, 1995) to describe the status of pre-service music teacher occupational identity at one institution during a first-semester beginning conducting course. Using a community of practice framework (Wenger, 1998), I examined the following questions: (1) how does conducting instruction influence the development of pre-service music teacher occupational identity; (2) how does a student's perceived trajectory relate to their approach to conducting instruction; (3) how does a student's previous and current socialization impact the awareness and participation in a conducting community of practice? Data analysis suggested four primary themes: (a) conducting as teaching; (b) conducting as performing; (c) participants learn by watching others conduct; (d) participants seek to assume the role of the expert. Findings suggest that a pre-service music teacher's occupational identity is affected by their perceived trajectory (Wenger, 1998) as they interact in or move through a community of practice.
\end{abstract}

Keywords: music education, teacher preparation, occupational identity, communities of practice, instrumental conducting

\section{Introduction}

Music teachers, especially those who teach in secondary public schools in the United States, often find themselves conflicted as to their status as a performing musician and professional educator. As a result, it is common for teachers in these settings to speak about their many hats - conductor, teacher, performer, and musician to name but a few. Among these multifaceted identities, ensemble conducting is a practice often perceived to be of importance to music teachers, music teacher educators, and pre-service music teachers. As teachers in training, undergraduate music education students are typically introduced to conducting during a one-semester course that emphasizes skill development with a projected outcome of basic conducting and rehearsal technique (Romines, 2003). While learning to conduct is a requirement in many music education undergraduate degree programs (National Association of Schools of Music, 2009: 98), little is known about how conducting instruction influences the development of pre-service music teacher occupational identity.

Occupational identity is thought to grow out of a person's relationship to their occupational title, which ultimately becomes a symbol of the shared values and norms of an occupational group (L'Roy, 1983). Traditionally, self-perceived symbolic interactionist frameworks have been used to identify three sub-constructs of pre-service music teacher occupational identity: musician identity, teacher identity, and teacher identity as inferred from others (Isbell, 2008). Still, a more outward and sociocultural conception of occupational identity may be of value when seeking to understand the development of one's professional trajectory and commitment to their chosen profession (Wenger, 1998). According to Wenger, "[as] we go through a succession of forms of participation [in a community of practice], our identities form trajectories, both within and across communities of practice" (p. 154). Identity, as conceived by Wenger, is a 
developmental trajectory that refers to a person's past, present, and perceived future interactions within a community of practice (COP). The notion that students would actively embrace, encounter, and negotiate different trajectories provides a unique window into the complexity of pre-service music teacher occupational identity development.

According to Pellegrino (2009), little is known about how the musician/performer identity informs music teacher identity or how the two identities may be integrated. Moreover, Roberts (1991) states "to understand the person who has constructed an identity as a music teacher, we need to unpack the social world in which the opportunities and obligations to construct these identities occur" (p. 38). While some researchers have framed the occupational identities of music educators as being discrete (e.g., a music teacher holds a performer or teacher identity) and therefore in competition with each other (L'Roy, 1983; Roberts, 1991; Rose, 1998), others call for a more sociocultural view where differing identities not only compete, but often complement and enhance each other (Conway, Eros, Pellegrino, \& West, 2010; Pellegrino, 2009; Woodford, 2002). Hence, as an external display of musicianship and performance practice while teaching, conducting practice may be an arena where the integration of teacher and performer identities for pre-service music educators can coexist. However, no studies have investigated the ways in which conducting instruction influences the occupational identity development of pre-service music educators.

The vast majority of pre-service music education students are well socialized to the consilience of conducting and teaching as a result of observational apprenticeship nurtured by the hundreds of hours spent in rehearsals observing their teachers conduct. Given this fact, it is not surprising that when asked about significant others who have influenced their development, pre-service music teachers most often name prior high school and current college ensemble conductors (Bauer \& Berg, 2001; Isbell, 2008; L'Roy, 1983). However, an examination of how conducting instruction incites the active negotiation of performer, teacher, and musician trajectories is needed to better understand the occupational identity development of pre-service music educators, especially those who aim to teach at the secondary level.

Through the use of qualitative case study methodology (Stake, 1995), I sought to examine and describe the status of pre-service music teacher occupational identity at one institution during an introductory conducting course. Specifically, my aim was to answer the following questions: (1) how does conducting instruction influence the development of pre-service music teacher occupational identity; (2) how does a student's perceived trajectory relate to their approach to conducting instruction; (3) how does a student's previous and current socialization impact the awareness and participation in a conducting community of practice?

\section{Theoretical Framework}

\section{Communities of Practice as a Means to Investigate Occupational Identity}

The theoretical concept of 'COP' asserts that individual knowledge is socially constructed as humans interact toward a common purpose over time (Wenger, 1998). Participation in a COP entails "being active participants in the practices of social communities and constructing identities in relation to these communities (Wenger, 1998: 4)." A person's role and involvement in a community can range from being an apprentice with peripheral participation to a master who fully participates -- or has participated -- in all aspects of community activity.

As a participant negotiates their role in a community, identity takes the form of an individual trajectory that can be characterized as "a path of learning through which we define who we are by where we have been and where we are going" within a COP (Wenger, 1998: 149). Wenger's 'path of learning' or 'trajectory' in the present study was used to identify how participation in an introductory conducting course influences the development of occupational identity.

The way that a participant negotiates their membership within a community is affected by their trajectory. Wenger (1998) has defined five trajectories that highlight the range of possibilities for membership within a community of practice (p. 154-55, three of which were germane to this study: peripheral trajectories, boundary trajectories, inbound trajectories). The peripheral trajectory may never lead to full participation, yet may provide a kind of access to a community that becomes significant enough to contribute to one's identity. The inbound trajectory is a newcomer joining a community with the prospect of becoming a full participant. Their identities are invested in future participation although their present participation may be peripheral. A boundary trajectory is most delicate as the participants' identity spans across boundaries and links communities together. The following conceptual framework illustrates the concept of the three trajectories just mentioned. 


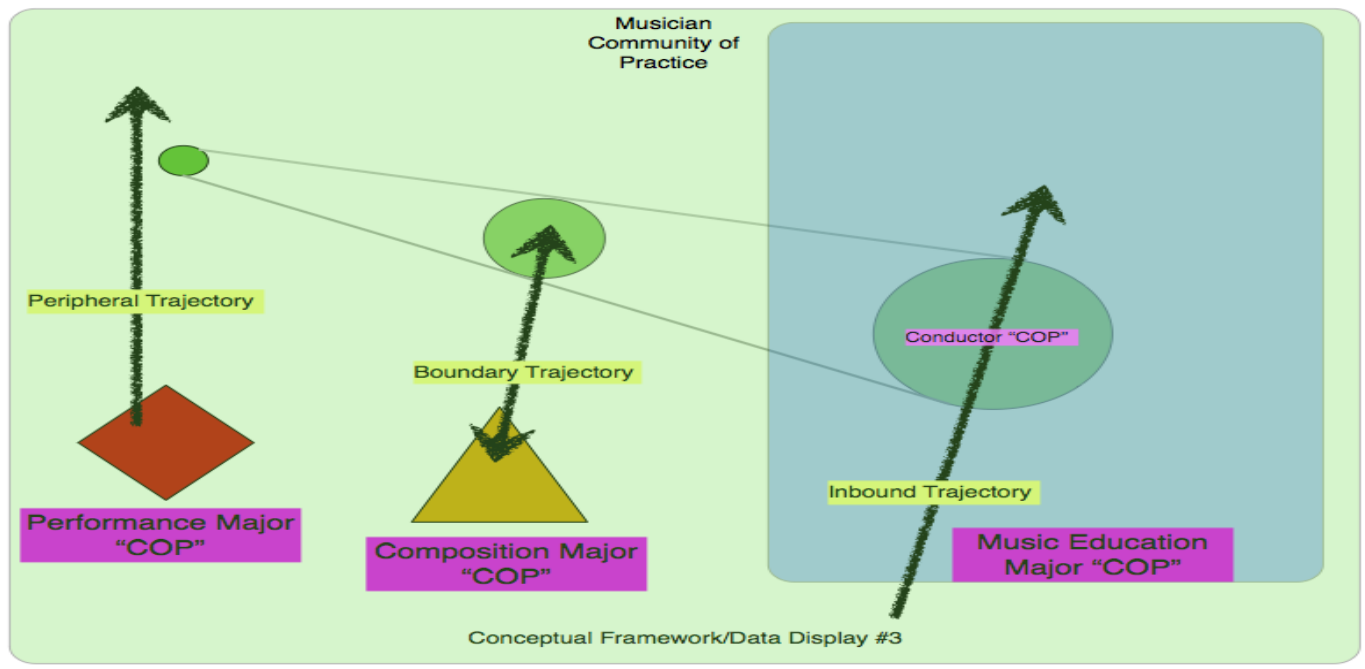

Figure 1. Undergraduate conductor trajectories.

Student participation in ensembles led by a conductor makes them a peripheral participant in a conducting community. This type of indirect participation is what Lave and Wenger (1991) call Legitimate Peripheral Participation which can be characterized when participant interacts within a community, however may or may not become a full-participant in that community. A performance major may never intend to become an ensemble conductor and a composition major interacts with conductors who premier their music but rarely conduct their own compositions. In contrast, a pre-service music teacher who eventually will conduct a secondary school ensemble has most likely set their trajectory to become a full participant in the conducting community of practice.

For the pre-service music teacher, ensemble conducting is a community with its own customs, expectations, and competencies that could be considered an overlap practice connection (Wenger, 1998: 115) within the larger community of music teaching (see figure 1). Through observing and interacting with members of a community that are full-participants -- such as through initial observation of conductors in ensemble rehearsals and short practicum conducting experiences -- new participants in a community are influenced by trajectories taken by full-participants. Wenger calls these "paradigmatic" trajectories that "embody the history of the community and the participation and identities of the practitioners" (p. 156).

Several socialization studies have posited the existence of competing identities between teaching and performing among music education students (Benyon, 1998; Isbell, 2008; L’Roy, 1983; Pellegrino, 2009; Roberts, 1991; Rose, 1998, Woodford, 2002). The final report of the Music Educators National Conference commission on Teacher Education in Music (1972) states "music education majors should internalize the role of the teacher and not the performer" (p. 48). In contrast, Wenger (1998) states that "identity is more than just a single trajectory; instead, it should be viewed as a nexus of multimembership" (p. 159).

Countering the dichotomous theoretical stance that places teacher and musician identity in conflict with each other, Conway, et al. (in press) suggest that students who participated in their study "truly seemed interested and excited about becoming the best music teachers they could be while still becoming the best instrumentalists and musicians they could be. Instead, for the participants studied, conflict often stemmed from a practical matter; the demands of each program time-wise" (p. 9). Scheib (2007) concerning the existence of two identities states that possible solutions could be the increased socialization of pre-service music teachers; or, to make efforts to engage the musician-performer identity throughout one's teaching career.

Conway et al. (2010), put forth the notion that many students enter college with their own musical development as a major personal goal and that views of themselves change as they continue through an undergraduate music education program. Dolloff (2006) states "[we] construct a dynamic and evolving sense of who we are through our experiences and relationships to our environment, others, and the results of our actions" (p. 125). These views may be congruent with notion that as students are socialized into a COP, they are able to adopt a more clearly defined trajectory as knowledge and awareness of that particular communities gestures become more transparent.

Highlighting the dichotomous relationship that many researchers have taken on the subject, Pellegrino (2009) writes "the music education literature suggests that, ideally, music teachers are integrated people who bring meaningful 
musical experiences with them into the classroom" (p. 51). Through the sociocultural theoretical framework presented by Wenger (1998), the concept that a participant can choose varied trajectories when negotiating their membership in different communities of practice provides a unique lens to understanding the complex inner-workings of pre-service music teacher occupational identity.

\section{The Site: Beginning Conducting Class}

A beginning instrumental conducting class at Estes College ${ }^{\mathrm{i}}$ a large institution of higher learning located in the western United States served as the data collection site. While two sections of this course were examined, a criterion sampling strategy (Kuzel, 1992; Patton, 1990) was used since nearly all instrumental music education students were enrolled in a single section. Also, an intensity sampling strategy (Miles \& Huberman, 1994) was used to identify three music education majors who displayed a strong interest in conducting and music teaching.

Formal undergraduate conducting instruction at Estes College begins in the fall semester of the junior year. After completing two years of rigorous musical training on their primary instrument, music theory, and introductory music education courses, the curriculum of the beginning conducting class focuses on the process of score analysis and on making interpretive decisions. Gesture and movement is taught as a means to communicate interpretive decisions to a lab ensemble comprised of those enrolled in the course. Meeting three times per week for fifty minutes, each section of the class follows the same syllabus which includes opportunities to study and conduct four musical excerpts taken from the following musical works: Dvorak (1878) Serenade for Winds, Op. 44; Beethoven (1808) Symphony No. 6, Op. 68; Copland (1944) Appalachian Spring; and Stravinsky (1918) L'Histoire du Soldat: The Royal March. Each excerpt represents one instructional unit that lasts approximately three weeks. Once during each unit, all members of the class lead the lab ensemble in their interpretation of the required excerpt. When not conducting, each student performs various parts of the score on their primary instrument to create a balanced sound as close to the composer's intent as is possible.

Prior to each unit, individual knowledge of the score is assessed through a written examination. The scores students receive on this test determines the order in which students conduct, with the highest score conducting first. Each conducting round is video recorded to facilitate reflection alone and at times with the aid of the instructor. Additionally, at the conclusion of each student's conducting performance, peers in the ensemble are asked to provide verbal comments to the student on the podium.

\section{Participants}

Allison is a junior music education major who plays the clarinet. She is tall with long curly brown hair and carries herself confidently. An out of state student, having graduated from a large high school in a suburb of Seattle with an outstanding music program, Allison believes that she knows what high quality music is and holds herself to high standards for both teaching, clarinet playing, and conducting performance. She frequently mentions the influence of her high school teacher who was constantly working on his conducting skills by attending workshops and by inviting other well-known conductors to observe and critique his conducting.

As a strong performer, Allison performs as principal clarinet in the one of the school bands and in the university symphony orchestra. She is seen at many evening recitals and always tends to make humble yet specific comments about the performances that she has just heard. As the chapter president of the Collegiate National Association for Music Education (CNAfME), she takes teaching very seriously. She is the lead undergraduate teacher in an evening lab ensemble made up of middle school band students where undergraduate music education students practice their teaching and conducting. She can often be seen at the student union talking with other undergraduate and graduate students about music teaching. Allison is a strong conductor. According to several of her peers and teachers, she is one of the best conductors in the junior class. She attends summer conducting symposiums as well as travels to international conferences to learn more about teaching and conducting.

In the conducting class, Allison is usually the first one to conduct, having scored the highest on the score knowledge test. She also is usually one of the first to make comments to other students in the conducting class. Allison's future plans are to be a public school music teacher either at the high school or middle school level. She has also expressed an interest in studying conducting at the graduate level.

Jennifer is a junior music education major who plays clarinet. Known for her happy demeanor, she has a smile that stretches from ear to ear. She began singing in a children's chorale when she was 10 years old, and as she says, "my early musical life was shaped much by choral music which I took into high school and earned a spot in the all-state choir." Jennifer started clarinet in the sixth grade and took that into high school as well. As she puts it, "at some point I had to choose. I was better at clarinet." 
As one of the strongest undergraduate clarinet players at her school, Jennifer plays in several chamber ensembles as well as the schools' wind symphony. Jennifer is a RA in a primarily music major residence hall, a job that she loves. She often practices her conducting by leading freshman instrumental music education students and asking them for their feedback. Jennifer plans to teach middle school music in a combined choir/band position. She has also indicated that she would possibly like to pursue a graduate conducting degree or degree in music education.

Alex is a junior music education major that plays saxophone. He attended a high school with a dichotomous population of low and high performing students drawn to the school by the International Baccalaureate (IB) program. Alex was identified as a gifted and talented student in fourth grade and has demonstrated his abilities in a variety of ways. His interest in composition began while a freshman in high school at a marching band rehearsal when one of his teachers handed him a college theory book. It didn't take Alex long to master the book and he was soon after trying his hand at composition for a variety of ensembles. Until he was a senior in high school, he wanted to pursue composition as a career. The experiences that he had as high school drum major fostered a desire to pursue music teaching as a career. Alex enjoyed the authority he was given as drum major as he was often given the responsibility of running entire marching band rehearsals. Having already conducted some of his original compositions and arrangements, he was familiar with conducting and excelled as drum major.

At the college level, Alex takes performing very seriously. He puts in many hours researching the history and common performance practices of the pieces he performs. He is perhaps the strongest conductor in his conducting class, where his experience shows through his confidence on the podium. He is often one of the first students to speak, offering comments to other conducting students. Alex also talks often about his desire to become a professional conductor and of the professional conductors he idolizes. He talks about going to graduate school for conducting as a certain aspect of his future.

\section{Data Collection}

Data were collected via observation of thirty-one classes over the course of one semester, formal and informal interviews (Lichtman, 2010; Spradley, 1979), and miscellaneous artifacts/documents (Creswell, 2007). Field notes were taken during each observation and were later constructed into expanded field notes that also included observer comments (Bodgan \& Biklen, 1982). Each participant was interviewed on five occasions with interviews lasting typically one-hour in length. An interview guide that included descriptive, structural and contrast questions (Spradley, 1979) served as a framework for each interview. Interview transcripts included verbatim text and nonverbal information (Ochs, 1979) to provide additional context beyond the written text. Artifacts included participant reflections, class syllabi, scores, video recordings used during participant interviews employing stimulated recall methodology (Gass \& Mackey, 2000; Austin \& Miksza, 2009).

Data management and coding were facilitated through the use of procedures outlined by Miles and Huberman (1994: 45) and included (a) formatting, (b) cross-referencing, (c) indexing, (d) abstracting, and (e) pagination. Cross-referencing was used by referencing line numbers between documents in addition to using colors to represent five major deductive pattern code areas. Colored sections representing different codes in field notes, interview transcripts, and participant reflections were cutout of their respective document and grouped together to facilitate triangulation and analysis (Miles \& Huberman, 1994; LeCompte \& Schensul, 1999). Indexing of codes was a process of defining representative examples of a specific code as well as indicating its location by color as previously noted. Abstraction was realized through, (a) content and document summary forms, (b) and conceptual framework revisions that included emerging themes.

Ethical Validation (Creswell, 2007) played a major part in attempting to create a critical stance for this study. I strived to build a rapport that participants trusted and would not be seen as judgmental of their conducting and teaching technique. Evidence of this cultivated rapport was shown through the comfort that participants displayed during interviews talking about the conducting class with me as if I were a peer.

\section{Data Analysis}

Coding began with the use of low-level inference, inductive codes (LeCompte \& Schensul, 1999), and progressed to the use of high-level inference, deductive codes. Inductive coding represented the emic participant perspective. Deductive coding reflected theoretical concepts found in research literature in addition to information gained from inductive coding (LeCompte \& Schensul, 1999; Miles \& Huberman, 1994). Pattern level coding assisted in the synthesis of inductive and deductive coding into categories that were authentic to this study. A total of thirty-one codes in five theoretical categories (community of practice, role identity, socialization, linguistic competence, and gestural competence) derived from the theoretical framework for the study served as the codebook used for data analysis.

Several strategies identified by Miles and Huberman (1994) and Creswell (2007) were used to increase the trustworthiness (Lincoln \& Guba, 1985) of the findings. These strategies included: (a) triangulation (methodological, 
source, and theoretical triangulation); (b) member checks; (c) peer-debriefing; (d) time sampling; and (e) prolonged engagement. Participants read over coded transcripts to discuss emerging themes identified by the researcher. In many cases, participants sought clarification of theoretical concepts and after reaching a point of understanding, agreed with emerging themes presented by the researcher. In a few cases, participants drew the researchers attention to additional passages that could be coded differently, an event which highlights the multifaceted nature of pre-service music teacher identity.

Additional insights into the complexity of factors that influence a person's trajectory through a COP were also revealed during peer-debriefing discussions. Finally, time sampling and prolonged engagement were strategies used to increase validity by observing of each of the two conducting classes during each class session for nearly the entire semester. Other strategies contributed to the reliability of findings and included immediate completion of expanded field notes and content summary forms after observations, embedding observer comments into the narrative of field notes, and making all data visible at once by attaching all documents to 3' x 5' cardboard sheets. As described by Anfara, Brown, and Mangione (2002) an audit trail was used to keep track of changes in conceptual framework, subcategories of research questions, changes in coding, and interview guides.

\section{Themes}

Data gathered during this study support four major themes: (1) participants feel that conducting is often synonymous with teaching; (2) participants view conducting as a performance outlet where they can apply their musicianship; (3) participants' observation of other conductors represents a means of learning how to conduct; and (4) music education students seek to assume the role of the conducting expert.

\section{Theme \#1: Conducting as Teaching}

One of the most common responses present in interview data is that participants view conducting as synonymous with teaching. Allison explains:

I would like to continue going to conducting symposiums and all of that, cause I feel like, as my job my conducting will become my instrument.

Allison goes onto reinforce the notion of conductor as teacher that her college experience has fostered:

...good conducting takes the verbal out, like the excess verbal element out of teaching...I feel like you don't have to say play this louder if you can make this [puts hands up with palms out] that the ensemble will react to. So I think conducting is teaching pretty much. I mean, that's what we do here. We learn about the music through the conducting.

Jennifer explains the relationship between conducting as teaching with the analogy of "killing two birds with one stone" in the following statement:

I think that you can teach more when you conduct in a sense because you're not speaking. You're making more music...so you can express things through your conducting that you would have ordinarily spoken, and that's BETTER... if you're doing the same thing while the music is being made, it's like you're killing two birds with one stone...

Alex explains how conducting and teaching interact in terms of how well you know the music your teaching:

I think that conducting and teaching are somewhat synonymous in some cases. I mean, as a conductor you're supposed to be more or less teaching your ensemble how to play the piece of music and if you don't know yourself how the music should be played, then you really can't teach it. You can teach through your visual interpretation and how you conduct a piece of music, I mean, you can change the way somebody thinks about a piece of music by one simple gesture, passive or aggressive gesture, you can change something like that (snaps) in an instant. So to me as a conductor I think you are one of the strongest teachers there is...

Theme \#2: Conducting as Performance

Conducting as performance was seen by the participants in this study to be an outlet where they could employ their musicianship skills that they have developed on their instruments. This finding suggests that conducting is a place where the skills learned as a performer and teacher can synergistically come together. Jennifer expresses this notion in the following statement:

Well, I mean I sort of think they are mutually depended on each other. Well, because when you're performing you express yourself through your instrument. And how can you teach music...music is all 
about expression... and you can't teach music without expressing yourself in someway. Conducting is a way that you can express yourself in how you feel about things musically...

Alex, in response to a question between how conducting compares to performance on his instrument, notes how conducting and performance are similar in the following statement:

I think they are about the same. Its [conducting] on a much larger scale because you're dealing with not only your instrument with the baton and everything else, but you're dealing with--lord only knows how many other instruments -- so you have to spend many more hours preparing the score and knowing everything that's involved.

Allison compares the similarities between preparing to conduct and preparing to perform on her instrument in the following statement:

When it comes to the actual day of conducting, I would say that it's pretty similar to the process that I go through when I prepare to perform on my instrument. I just try to calm myself, focus on the music, figure out the mood... whatever mood I'm going after. So I try to embody all of that and figure out how to get myself into a centered place ready to go when I step on the podium.

Theme \#3: Students Learn by Watching Others Conduct

Evident in the process of data collection and data analysis was that participants in this study were aware of their situated nature as students among many students of conducting. All music education participants referenced the impact that watching other conductors receive peer-generated critique had on their own development. This notion supports the concepts of "mutuality of engagement" (Wenger, 1998) and 'gesture' (Blumer, 1969) as a participant in a community acquires knowledge of gestures and common practices within a community by watching others perform similar tasks. This theme also supports the notion that music education majors have an inbound trajectory (Wenger, 1998) and aim to become full-participants in a community that values conducting as a key skill.

Allison made a statement that highlights how she learned from watching other conductors. She enthusiastically describes the influence that her high school teacher had on her conducting development in the following statement:

My high school director was participating in a conducting symposium and there were like five or six conductors. He conducted Horkstow Grange, a portion of Lincolnshire Posy. It was SO interesting...I had NO IDEA what was going on until someone explained it to us...my director was definitely on the better end of the spectrum of what we saw. I learned SO much about...just...the entire process and everything that goes into it. So that was when I first realized what the job of the conductor entailed. And then, I think I had more attentiveness to it from then on. I learned a lot from just observing conducting in ensembles...professor Smith does a lot of critiquing of the graduate students and so I learned quite a bit from just sitting there and watching and listening. So...I think that all of that has really informed my conducting and...um...now, like whenever I go to the professional symphony, I kinda check-out who is up there and what is going on...it is very interesting to see all of the different styles...it's [conducting] just everywhere...it's everywhere.

Jennifer describes the dramatic impact that her first college ensemble experience had on her concept of conducting:

Well, I remember like, my freshman year in symphonic band...sorry to keep bringing things back to professor Smith ${ }^{i i}$, but I really enjoy his conducting. I remember the first time he started talking about conducting with the graduate students, he put his hand out in front of the ensemble. All he had the ensemble do was play a $C$ major chord and all he did was change the angle of his hand and the sound of the ensemble changed... and I remember thinking OH MY GOSH. I had no idea that conducting could do that.

Alex describes how his observations of college professors teaching and conducting contributes to the knowledge that he expects to draw from as a future teacher and conductor:

As far as conducting and teaching goes, I just kinda take lessons from other people. Like how professor Smith and Dr. Brown ${ }^{i i i}$ run their rehearsals differently from each other and kinda use all of that as kind of a good idea. Maybe I should use that when I'm conducting.

Theme \#4: Seeking to Assume the Role of the Expert

A final theme is that music education students have a personal concept of the abilities and role of the expert in conducting community, and that they seek to eventually acquire the abilities of that expert. Expert abilities in the realm of conducting are seen by Alex as the need to gain the ability to look at and interpret scores on her own: 
Conducting is another outlet where I can try and work on two things at once [performing and conducting]. I feel like I need more chances to look over scores and decide interpretations of them...I don't know if I have the skills yet to look at a fresh score and put together some sort of movements that match my interpretation and look like the music.

Jennifer outlines a transparent view of the qualities that she seeks in becoming a successful conductor:

I think that to be a conductor, you need to be a musician, you need to be a collaborator, you need to be a leader, and you need to be very prepared. You need to be connected to the world, and in that I mean what's happening in other fields, reading books and just being connected to life, and being connected to other humans...I think that these are all really important qualities that I want to cultivate as a conductor in order to have the best...the ultimate musical experience.

Alex is an avid watcher of YouTube videos of the famous, late, professional conductor Herbert von Kjarian, and cites the influence that watching him conduct has had on his own development:

Herbert von Kjarian is a big role model of mine... his interpretations are some of the best that I've ever heard. Hands down! He conducts $90 \%$ of the time with his eyes closed and to me that just shows that the music is in him. He has looked at those scores so much that he has got them memorized. Just to know that the music is inside of him that much...that's a huge influence on me.

\section{Discussion}

The four main themes that the data suggest in this study provide interesting and varied answers to the research questions: (1) how does conducting instruction influence the development of pre-service music teacher occupational identity; (2) how does a student's perceived trajectory relate to their approach to conducting instruction; (3) how does a student's previous and current socialization impact the awareness and participation in a conducting community of practice?

The first theme, conducting as teaching supports the notion that pre-service music teacher's occupational identity can be viewed as a single construct when viewed through the lens of conducting. Conducting, as perceived by participants in this study, is an artistic skill that they will need to possess as a teacher. This finding supports the suggestion put forward by Pellegrino (2009) who favors a holistic view of pre-service music teacher identity. This view of identity frames music teachers as "fully integrated people who bring meaningful musical experiences with them into their classrooms (p. 50)." Conducting is part of the fully integrated music teacher. In the words of one participant, a capable conductor is "one of the strongest music teachers there is."

Participants in this study all commented on the influence of their high school music teachers. Having been socialized to the norms of teaching through many years of observing their own music teachers (Benyon, 1998; Isbell, 2008), this finding supports the notion that music education students are influenced through the observation of primary significant others (Blumer, 1969). Additionally, participants also commented on the impact of guest conductors that they interacted with during their public school years on their conceptualization of teacher as conductor.

Also implicit to this finding is that as students seek to become a teacher, they often replicate the actions of their own teachers. Woodford (2002) cites that many students decide to pursue music education while still in high school, which is the case for all three participants in this study. It is perhaps a significant finding that if a student chooses to pursue a music teaching career while still in high school, that conducting ability is part of the influence had by their high school teachers and that they as future teachers seek to fulfill that role themselves as conductors.

A possible refute to this notion is that two out of the three participants made statements regarding the lack of conducting accomplishment of their high school music teacher, yet they still saw them as effective inspirational teachers. Perhaps by coming to the realization that conducting is an important ability to possess as a music teacher, the participants -- by trying to imitate their more expert collegiate conductors -- are trying to surpass the conducting ability of their previous music teachers. It seems that participants in this study have an idealized image of what a successful music teacher can do. Through being socialized with conductors of high quality, it is plausible that participants might be seeking to effectively raise the bar in their idealized future teaching.

The second theme, conducting as performance is interesting considering that participants also consider conducting as teaching. This intersection seems to be an important one as it is rare for the aspects of performing and teaching to come together so strongly -- especially noting its absence in previous research (Pellegrino, 2009; Roberts, 1991). Participants commented on how conducting is an art form and that the process of preparing to conduct is very similar to the process of preparing to perform on their instrument. In fact, participants went into great detail about how the process between the two is one in the same, "like killing two birds with one stone." With so much emphasis given to performer and teacher identity being separate in previous research literature, I believe this to be a major finding. Conway et al., (2010) found that music education students that participated in their study were just trying to become the best teacher and 
performer that they could be. Conducting is perhaps an opportunity for the music educator to work on performance skills that will have a direct, meaningful impact on their teaching ability. This is not to say that all great conductors are great teachers, but good conducting skills could certainly compliment other areas of strength for the artist teacher.

One participant stated, "someday, conducting will become my instrument" and went on to say that he "would like to continue attending conducting workshops and possibly pursue a masters degree in conducting." This sentiment indicates an idealized professional future where conducting plays a major role. Many of the participants in Roberts' (1991) study indicated that, even upon graduation from a teacher-training program, they felt more comfortable being considered a musician and performer rather than a teacher. When the identities of teacher and performer are considered to be so extremely different, one might consider conducting to be a place where there is mutual ground.

The third theme, learning how to conduct by watching others highlights the situated nature of music education majors in a community of conductors as teachers. All participants highlighted how much they learned from watching graduate students conduct. This suggests that music education students who perform in ensembles with graduate conductors are socialized to the norms of conducting before entering beginning conducting classes. However, participants who are performance majors in the same ensembles did not mention this socialization. Music education students that see conducting as an important aspect of teaching may be more likely to see advanced conductors as sources for learning. As stated by one music education participant "there is a lot more at stake for the music educator when it comes to studying conducting."

As music education students observe other more expert conductors on the podium they are acting as legitimate peripheral participants (Lave \& Wenger, 1991) in a conducting community of practice (Wenger, 1998). They have chosen an inbound trajectory (Wenger, 1998) into a teaching community of practice where conducting skill is valued. Their membership status changes from legitimate peripheral participant (LPP) to a participant seeking full-membership status in a conducting community during their time in beginning conducting class. The skills previously gained as a LPP develop additional meaning once participants seek full-membership and start to work on the very same skills that they have observed others work to master.

The fourth theme, seeking to assume the role of the conducting expert, is in close relationship with the third theme as they both together illuminate the situated nature of the pre-service music teacher as a student of conducting. Participants in this study highlighted the different roles that a conductor must fill, the need to be able to interpret scores, and the need to know the music so well as to have the music speak from within themselves. All four themes highlight the transparency with which participants view the actions and abilities of the expert conductor. As a participant with an inbound trajectory (Wenger, 1998), participants see themselves filling these roles in the future as teachers through a process of ventriloquation $^{\text {iv }}$ (Bakhtin, 1953/1981).

The findings present a view of pre-service teacher occupational identity through the lens of conducting. This view is in contrast with the view taken by many of the previous investigations of socialization and identity that frame performing and teaching as separate identities that often compete with each other (L'Roy, 1983; Roberts, 1991). The findings of this study suggest that conducting plays a significant role in the identity construction of the pre-service music educator. This may be especially the case for those who plan to teaching at the secondary level. It is also apparent that conducting is a place where performer and teacher identities can come together in a way that is meaningful to participants. Possible implications of the information presented here would be for all college music faculty and high school music teachers to encourage and support pre-service music educators in their pursuit of conducting skill. Knowing that situated learning is a powerful tool for conducting instruction, providing curricular conducting experiences of varying degrees that integrate students of varying conducting abilities during all four years of a music education program may help the secondary pre-service music teacher bring performance skill to teaching in a meaningful way. The teachers of conducting courses should also be aware that it is possible that music education students will have a deep connection to the course and will likely bring ideas and pre-formed opinions about the role of the conductor. Noting the benefits of situated learning (Lave \& Wenger, 1991) cited by participants in this study, efforts should be made to engage ensemble members to verbally reflect on the conductors that they work with.

It would be useful for future studies that look at occupational identity construction through the lens of conducting to use larger populations and sample sizes in varied settings to deepen the understanding of the themes found here. It would also be useful to investigate the nature of specific conducting cultures at varying universities to note the effect that differing approaches to conducting instruction have on pre-service music teacher identity. Researchers interested in music teacher identity should continue to investigate the role that conducting plays in identity construction.

Undergraduate music education majors enter college with hopes of becoming better teachers and musicians. While on their journey, they are surrounded by myriad influences and opportunities that can shape who they will become professionally and the resources to develop the ideas they will draw from as practicing teachers. As affirmed by one 
participant, 'conducting is everywhere' during this journey and appears to make a lasting impact on the identity construction of the pre-service teachers in this study. While there are many complex factors that can be relatively idiosyncratic to the development of pre-service music teacher identity, conducting seems to be an authentic combination of musicianship and teaching skills that when investigated, can reveal a tremendous amount of information about the developing occupational identity of the undergraduate music education student.

\section{References}

Anfara, V. A., Jr., Brown, K. M., Mangione, T. L. (2002). Qualitative analysis on stage: Making the research process more public. Educational Researcher, 31, 28-38. http://dx.doi.org/10.3102/0013189X031007028

Austin, J., \& Miksza, P. (2009, September). Trying on teaching. Paper presented at the Society for Music Teacher Education 2009 National Symposium on Music Teacher Education, Greensboro, NC.

Bakhtin, M. M. (1953/1981). Discourse in the novel. In M. Holquist (Ed.), The dialogic imagination: Four essays (pp. 259-422). Austin: University of Texas Press.

Bauer, W., \& Berg, M. (2001). Influences on instrumental music teaching. Bulletin of the Council for Research in Music Education, 150(3), 53-66.

Beethoven, L. (1808). Symphony No. 6 in F major [Musical Score]. Mineola, NY: Dover $\quad$ Publications.

Benyon, C. (1998). From music student to music teacher: Negotiating an identity. Studies in Music from the University of Western Ontario, 17, 83-105.

Berger, P. L., \& Luckmann, T. (1966). The social construction of reality: A treatise in the sociology of knowledge. Garden City, NY: Doubleday.

Blumer,H. (1969). Symbolic interactionism: Perspective and method. Englewood Cliffs, NJ: Prentice Hall.

Bodgan, R. C., \& Biklen, S. K. (1982). Qualitative research for education: An introduction to theory and methods. Boston: Allyn and Bacon.

Conway, C., Eros, J., Pellegrino, K., \& West, C. (2010). Instrumental music education student perceptions of tensions experienced during their undergraduate degree. Bulletin of the Council for Research in Music Education,183(4), 49-64.

Cox, P. (1997). The professional socialization of music teachers as musicians and educators. In R. Rideout (Ed.), On the sociology of music education (pp. 112-120). Norman: University of Oklahoma Press.

Copland, A. (1944). Appalachian Spring [Musical Score]. New York: Boosey \& Hawkes.

Creswell, J. (2007). Qualitative inquiry and research design: Choosing among five approaches (2nd ed.). Thousand Oaks, CA: Sage Publications.

Dolloff, L. (2006). Celebrating and nurturing the identity of the musician/teacher. In B. Stalhammar (Ed.), Music and human beings: Music and identity. (pp. 123-136). Orebro, Sweden: Universitetsbiblioteket.

Dvorak, A. (1878). Serenade No. 2 in D minor [Musical Score]. Mineola, NY: Dover Publications.

Gass, S., \& Mackey, A. (2000). Stimulated recall methodology in second language research. Mahwah, NJ: Lawrence Erlbaum Associates.

Isbell, D. S. (2008). Musicians and teachers: The socialization and occupational identity of pre-service music teachers. Journal of Research in Music Education, 56(2), 162-178. http://dx.doi.org/10.1177/0022429408322853

Kuzel, A. J. (1992). Sampling in qualitative inquiry. In B. F. Crabtree \& W. L. Miller (Eds.), Doing qualitative research (pp. 31-44). Newbury Park, CA: Sage Publications.

LeCompte, M. D., \& Schensul, J. J. (1999). Analyzing and interpreting ethnographic data. Walnut Creek, CA: AltaMira Press.

Lave, J., \& Wenger, E. (1991). Situated learning: Legitimate peripheral participation. Cambridge, UK: Cambridge University. http://dx.doi.org/10.1017/CBO9780511815355

Lichtman, M. (2010). Qualitative research in education: A user's guide (2nd ed.). Los Angeles, CA: Sage Publications. Lincoln, Y. S., \& Guba, E. G. (1985). Naturalistic inquiry. Beverly Hills, CA, Sage Publications.

L'Roy, D. (1983). The development of occupational identity in undergraduate music education majors. Unpublished doctoral dissertation, North Texas State University, Denton. 
Miles, M. B., \& Huberman, A. M. (1994). Qualitative data analysis (2nd ed.). Thousand $\quad$ Oaks, $\quad$ CA: $\quad$ Sage Publications.

Music Educators National Conference. (1972). Final report of the Commission on Teacher Education in Music. Reston, VA: Author.

National Association of Schools of Music. (2009). Handbook 2009-2010. Reston, Virginia: Author.

Ochs, E. (1979). Transcription as theory. In E. Ochs \& B. Schieffelin (Eds.) Developmental pragmatics, 43-72. NY: Academic Press.

Patton. M. Q. (1990). Qualitative evaluation and research methods (2nd ed.). Newbury Park, CA: Sage Publications.

Pellegrino, K. (2009). Connections between performer and teacher identities in music teachers: Setting an agenda for research. Journal of Music Teacher Education, 19(1), 39-55. http://dx.doi.org/10.1177/1057083709343908

Roberts, B. A. (1991). Music teacher education as identity construction. International Journal of Music Education, 18, 30-39. http://dx.doi.org/10.1177/025576149101800104

Romines, F. D., (2003). A survey of undergraduate conducting curricula. Journal of Band Research, 38(2), 80-90.

Rose, A. M. (1998). Exploring music teacher thinking: A reflective and critical model. Studies in Music from the University of Western Ontario, 17, 23-44.

Scheib, J. W. (2007, September). Music teacher socialization and identity formation: Redesigning teacher education and professional development to enhance career satisfaction. Paper presented at the Society for Music Teacher Education 2007 National Symposium on Music Teacher Education, Greensboro, NC.

Spradley, J. (1979). The ethnographic interview. New York: Holt, Rinehart \& Winston.

Stake, R. (1995). The art of case study research. Thousand Oaks, CA: Sage Publications.

Stravinsky, I., \& Ramuz, C. F. (1918). L' Histoire du Soldat [Musical Score]. London: Chester Music.

Teachout, D. (2009, October). Research on music teacher pedagogy: Exploring the impact of innovation on music teacher thinking and practice. Paper presented at the 10th International RAIME Conference, Gothenburg, Sweden.

Wallace, R. A., \& Wolf, A. (1999). Contemporary sociological theory: Expanding the classical tradition (5th ed). Upper Saddle River, NJ: Prentice-Hall.

Wenger, E. (1998). Communities of practice: Learning, meaning, and identity. New York: Cambridge University Press. http://dx.doi.org/10.1017/CBO9780511803932

Woodford, P. G. (2002). The social construction of music teacher identity in undergraduate music education majors. In R. Colwell, \& C. Richardson (Eds.), The new handbook of research on music teaching and learning. (pp. 675-694). NY: Oxford University Press.

Wright, J. E. (1991). Belief systems and their influence on musical experience. (Unpublished doctoral dissertation). Northwestern University, Evanston.

\section{Notes}

\footnotetext{
${ }^{\mathrm{i}}$ Pseudonym used to protect the identity of participants

ii Pseudonym used to protect the identity of participants

iii Pseudonym used to protect the identity of participants

iv Due to space limitations, ventriloquation is not pursued in depth in this paper. For more information, see Bakhtin $(1953 / 1981)$.
}

\section{$(\mathrm{c})$ EY}

This work is licensed under a Creative Commons Attribution 3.0 License. 